\title{
A PROSPECTIVE CLINICO-PATHOLOGICAL STUDY OF ORAL LESIONS AND DIAGNOSTIC CORRELATION BETWEEN BRUSH CYTOLOGY AND HISTOPATHOLOGY
}

\author{
Aparaajita Upadhyay1, R. K. Mundra² \\ 1 Senior Resident, Department of Head and Neck Surgery, MGM Medical College and MY Hospital, Indore, M. P. \\ ${ }^{2}$ Professor and HOD, Department of Head and Neck Surgery, MGM Medical College and MY Hospital, Indore, M. P.
}

\section{ABSTRACT}

\section{BACKGROUND}

Oral carcinoma is the $6^{\text {th }}$ most common malignancy in western world and accounts for more than $40 \%$ cancers in the world. Normally, the standard practice to confirm the presumed clinical diagnosis is to take punch biopsy of the lesion. But exfoliative cytology being a non-invasive procedure has a better patient compliance.

Aims and Objectives- To evaluate the clinical profile of the patients of oral mucosal lesions and to find the diagnostic correlation between brush cytology and histopathology of these oral mucosal lesions as well as to see the histopathological pattern of these lesions and to establish the factors which are usually causative to such malignant oral lesions.

\section{MATERIALS AND METHODS}

60 cases with oral mucosal lesions were included in the study. All patients underwent oral brush cytology and punch biopsy. Sensitivity, specificity, positive and negative predictive values were calculated. Cytopathology and histopathology of the lesions were compared.

\section{RESULTS}

The incidences of oral cancer were very high among the age group of 42 - 50 years. Males were more affected (M: F 3.2: 1) and the most common site involved was the tongue. The sensitivity, specificity, positive and negative predictive values for malignant lesions were $92.7 \%, 80 \%, 98 \%$ and $50 \%$. Statistical analysis showed $\mathrm{p}<0.05$, suggesting that there is significant association between brush cytology and histopathology in assessing clinically premalignant and malignant lesions.

\section{CONCLUSION}

Oral brush cytology is an important screening tool for early diagnosis of oral cancer and is the key factor for its effective management. The fact that it is painless, easy to perform, has better patient compliance, has high specificity in both malign ant and premalignant lesions makes it an ideal screening test.

\section{KEYWORDS}

Punch Biopsy, Brush Cytology, Oral Mucosal Lesions.

HOW TO CITE THIS ARTICLE: Upadhyay A, Mundra RK. A prospective clinico-pathological study of oral lesions and diagnostic correlation between brush cytology and histopathology. J. Evolution Med. Dent. Sci. 2018;7(14):1699-1702, DOI: $10.14260 /$ jemds/2018/384

\section{BACKGROUND}

Oral cancer is a global health issue with increasing incidence and mortality rates. It is the $6^{\text {th }}$ most common malignancy representing $2 \%$ to $4 \%$ of the malignancies in the West and accounts for almost $40 \%$ of all cancers in the Indian subcontinent.[1] Oral cancers are the most common cancers among Indian population, and it accounts for $50 \%-70 \%$ of all cancers diagnosed in India.[2]

The risk of developing cancer increases with age. In UK, majority of cases $(86 \%)$ were found to be in the people aged 50 years or above. In India the presentation of oral cancer has been observed at a relatively earlier age, which may be due to frequent use of paan and areca nut in younger population. [3]

'Financial or Other Competing Interest': None.

Submission 07-02-2018, Peer Review 15-03-2018,

Acceptance 21-03-2018, Published 14-04-2018.

Corresponding Author:

Dr. Aparaajita Upadhyay,

C/o. Dr. R. K. Mundra,

\#104 President Regency,

3/5, Manorma Ganj,

Indore-452001,

Madhya Pradesh.

E-mail: draparaajita6@gmail.com

DOI: $10.14260 / \mathrm{jemds} / 2018 / 384$
The following entities have been suggested as possible predisposing factors in the formation of head and neck cancer: Exposure to tobacco, radiation, malnutrition, alcohol consumption, genetic susceptibility, viruses, syphilis and traumatic irritation. The high incidence of oral cancer in India has emphasised the relationship between tobacco chewing, smoking habits and oral cancer.[4] Oral cancers develop by transformation through precancerous lesion, subsequently developing into cancerous lesion. Precancerous lesions of oral mucosa known as potentially malignant disorders in recent years consists of a group of diseases which should be diagnosed in the early stage. Oral leukoplakia, oral submucous fibrosis and oral erythroplakia are the most common oral mucosal diseases that have a very high malignant transformation rate. [5]

Exfoliative cytology is commonly used in oral smears collected by cytobrush to show a significant improvement in smear thickness and cellular distribution, which leads to easier identification of abnormal cells.[6] Punch biopsy is the gold standard method for diagnosing oral carcinoma, but exfoliative cytology being a non-invasive procedure has a better patient compliance. The present study has been done to find out the efficacy of oral scrap smear as a screening tool for detecting oral carcinoma and to find its utility in detecting 
premalignant and malignant lesions in comparison to oral punch biopsy.

\section{MATERIALS AND METHODS}

60 patients with oral lesions reporting to the ENT OPD were selected for the prospective observational study design. A detailed history regarding presenting complaints, history of presenting illness, past history regarding tobacco chewing, smoking and any similar lesions or swelling and any chronic systemic illness like tuberculosis, hypertension, cardiac disease, asthma, diabetes etc. Patients were thoroughly investigated for complete haemogram, blood sugar, blood urea, serum creatinine, coagulation profile and chest x-ray for any secondary focus. Oral brush cytology was performed in all the 60 cases. Oral scraping was done with the help of brush. It is important to brush the edges of the ulcer as well as the floor in order to obtain diagnostic material and smeared onto the glass slide and it is immediately fixed with isopropyl alcohol (95\% absolute alcohol) and was sent for cytological examination.

The Slides were reported under the following Category-

1. Unsatisfactory: (a) Acellular or hypocellular; (b) Cellularity adequate, but poor air drying or fixation; (c) Too thick.

2. Positive for Malignant Cells: ${ }^{[7,8]}$ The smears are highly cellular with the following characteristics: (a) Ill-defined cell border; (b) High cellular atypia; (c) High nuclear atypia; (d) Enlarged nuclei with high N: C ratio; (e) Condensation of nuclear chromatin forming strands, coarse clumps and dense peripheral nuclear outlines; (f) Densely packed hyperchromatic nuclei in compact groups with no visible cell outline; (g) Multiple and enlarged nucleoli; (h) Multinucleated giant cells; (i) Tendency towards spherical shape; (j) Keratinized pearls of malignant cells are frequently seen; (k) Background is necrotic with blood and numerous leukocytes.

3. Suspicious for Malignant Cells (Dysplastic Cells): $[9,10]$ With following characteristics: (a) Hyperchromasia of nuclei; (b) Increased N: C ratio; (c) Anisonucleosis and Nuclear pleomorphism; (d) Irregularities of nuclear membrane; (e) Nuclear crowding: (f) Nuclear moulding, clumping and irregular distribution of chromatin.

4. Negative for Malignancy: Adequate cellularity, neither suspicious nor malignant cells present. The punch biopsy was also performed in all patients and sent for histopathological correlation.

Cytopathology and histopathology of the lesions were compared thereafter.

\section{RESULTS}

Of the total 60 cases, 2 cases were found to be inadequate on cytology. Clinically premalignant lesions included erythroplakia, leukoplakia and non-healing ulcers, whereas any oral growth was suspected as potentially malignant lesions. Demographic distribution illustrated male predominance with most common site to be tongue and tobacco chewing was found to be most common factor responsible for addiction (Table 1 ).

\begin{tabular}{|c|c|c|}
\hline Characteristics & & \\
\hline Age & Range & 18-65 \\
\hline \multirow{2}{*}{ Sex } & Male & $46(76.67 \%)$ \\
\hline & Female & $14(23.33 \%)$ \\
\hline \multirow[t]{2}{*}{ Lesions } & $\begin{array}{c}\text { Clinically } \\
\text { premalignant }\end{array}$ & 35 (58.33\%) \\
\hline & Clinically malignant & $25(41.66 \%)$ \\
\hline \multirow{7}{*}{ Site } & Tongue & $31(51.67 \%)$ \\
\hline & Buccal mucosa & $19(31.67 \%)$ \\
\hline & Palate & $3(5 \%)$ \\
\hline & Floor of mouth & $1(1.67 \%)$ \\
\hline & Lips & $2(3.33 \%)$ \\
\hline & Retromolar trigone & $2(3.33 \%)$ \\
\hline & $\begin{array}{c}\text { Upper and lower } \\
\text { alveolus }\end{array}$ & $2(3.33 \%)$ \\
\hline \multirow{6}{*}{ Addiction } & Tobacco chewing & $52(86.67 \%)$ \\
\hline & Smoking & $40(66.66 \%)$ \\
\hline & Alcohol & $36(60 \%)$ \\
\hline & Supari & $36(60 \%)$ \\
\hline & Betel nut & $32(53.33 \%)$ \\
\hline & Gutka & $28(46.67 \%)$ \\
\hline
\end{tabular}

\begin{tabular}{|c|c|c|}
\hline Report of Brush Cytology & No. of Cases & Percentages \\
\hline Negative for malignant cells & 6 & $10.0 \%$ \\
\hline Positive for malignant cells & 42 & $70.0 \%$ \\
\hline $\begin{array}{l}\text { Suspicious for malignant } \\
\text { cells }\end{array}$ & 10 & $16.7 \%$ \\
\hline $\begin{array}{l}\text { Unsatisfactory for } \\
\text { malignant cells }\end{array}$ & 2 & $3.3 \%$ \\
\hline Total & 60 & $100.0 \%$ \\
\hline \multicolumn{3}{|c|}{$\begin{array}{l}\text { Table 2. Distribution of Cases as reported by Brush } \\
\text { Cytology }\end{array}$} \\
\hline
\end{tabular}

\begin{tabular}{|c|c|c|}
\hline Report of Brush Cytology & No. of Cases & Percentages \\
\hline $\begin{array}{c}\text { Negative for malignant cells } \\
\text { (Negative + Unsatisfactory) }\end{array}$ & 8 & $13.3 \%$ \\
\hline $\begin{array}{c}\text { Positive for malignant cells } \\
\text { (Positive + Suspicious) }\end{array}$ & 52 & $86.7 \%$ \\
\hline Total & $\mathbf{6 0}$ & $\mathbf{1 0 0 . 0 \%}$ \\
\hline \multicolumn{2}{|c|}{ Table 3 } \\
\hline
\end{tabular}

\begin{tabular}{|c|c|c|}
\hline Report of Biopsy & No. of Cases & Percentages \\
\hline Non-malignant & 5 & $8.3 \%$ \\
\hline Malignant & 55 & $91.7 \%$ \\
\hline Total & $\mathbf{6 0}$ & $\mathbf{1 0 0 . 0} \%$ \\
\hline Table 4. Distribution of Cases as reported by Biopsy \\
\hline
\end{tabular}

\begin{tabular}{|c|c|c|c|}
\hline \multirow[b]{2}{*}{$\begin{array}{c}\text { Brush Cytology } \\
\text { Report }\end{array}$} & \multicolumn{2}{|c|}{ Biopsy Report } & \multirow[b]{2}{*}{ Total } \\
\hline & $\begin{array}{c}\text { Non- } \\
\text { Malignant }\end{array}$ & Malignant & \\
\hline $\begin{array}{c}\text { Negative for } \\
\text { malignant cells }\end{array}$ & $\begin{array}{c}3 \\
50.0 \%\end{array}$ & $\begin{array}{c}3 \\
50.0 \% \\
\end{array}$ & $\begin{array}{c}6 \\
100.0 \% \\
\end{array}$ \\
\hline $\begin{array}{l}\text { Positive for } \\
\text { malignant cells }\end{array}$ & $\begin{array}{c}0 \\
0.0 \%\end{array}$ & $\begin{array}{c}42 \\
100.0 \%\end{array}$ & $\begin{array}{c}42 \\
100.0 \%\end{array}$ \\
\hline $\begin{array}{l}\text { Suspicious of } \\
\text { malignant cells }\end{array}$ & $\begin{array}{c}1 \\
10.0 \%\end{array}$ & $\begin{array}{c}9 \\
90.0 \%\end{array}$ & $\begin{array}{c}10 \\
100.0 \%\end{array}$ \\
\hline $\begin{array}{l}\text { Unsatisfactory for } \\
\text { malignant cells }\end{array}$ & $\begin{array}{c}1 \\
50.0 \%\end{array}$ & $\begin{array}{c}1 \\
50.0 \%\end{array}$ & $\begin{array}{c}2 \\
100.0 \% \\
\end{array}$ \\
\hline Total & $\begin{array}{c}5 \\
8.3 \%\end{array}$ & $\begin{array}{c}55 \\
91.7 \%\end{array}$ & $\begin{array}{c}60 \\
100.0 \%\end{array}$ \\
\hline \multicolumn{4}{|c|}{$\begin{array}{c}\text { Table 5. Distribution of Cases according to Brush Cytology } \\
\text { in Relation to Biopsy Report }\end{array}$} \\
\hline
\end{tabular}




\begin{tabular}{|c|c|c|c|}
\hline \multirow{2}{*}{$\begin{array}{c}\text { Brush Cytology } \\
\text { Report }\end{array}$} & \multicolumn{2}{|c|}{ Biopsy Report } & \multirow{2}{*}{ Total } \\
\cline { 2 - 3 } & $\begin{array}{c}\text { Non- } \\
\text { Malignant }\end{array}$ & Malignant & \\
\hline Negative for & 4 & 4 & 8 \\
malignant cells & $50.0 \%$ & $50.0 \%$ & $100.0 \%$ \\
\hline Positive for & 1 & 51 & 52 \\
malignant cells & $1.9 \%$ & $98.1 \%$ & $100.0 \%$ \\
\hline Total & $\mathbf{5}$ & $\mathbf{5 5}$ & $\mathbf{6 0}$ \\
& $\mathbf{8 . 3 \%}$ & $\mathbf{9 1 . 7 \%}$ & $\mathbf{1 0 0 . 0 \%}$ \\
\hline \multicolumn{2}{|c|}{ Table 6. Association of Brush Cytology } \\
Findings and Biopsy Findings \\
\hline
\end{tabular}

( $P$ value $=0.000$, Significant $)$.

There is a statistically significant association seen between the findings of brush cytology and biopsy report $(\mathrm{P}<0.05)$, showing that brush cytology findings are associated with biopsy findings.

For malignant lesions, following findings hold true:*

\begin{tabular}{|c|c|}
\hline True positive & 51 \\
\hline False positive & 1 \\
\hline True negative & 4 \\
\hline False negative & 4 \\
\hline Sensitivity & $92.73 \%$ \\
\hline Specificity & $80.00 \%$ \\
\hline Positive predictive value & $98.08 \%$ \\
\hline Negative predictive value & $50.00 \%$ \\
\hline Diagnostic accuracy & $91.67 \%$ \\
\hline
\end{tabular}

*(Sensitivity and specificity for premalignant lesions could not be calculated separately due to very less sample size of only premalignant lesions).

\section{DISCUSSION}

Oral cancer is the commonest cancer in India accounting for $50 \%-70 \%$ of total cancer mortality. The incidence of oral carcinoma is increasing with the increasing use of tobacco and smoking. Biopsy is considered as the gold standard for diagnosing oral lesions, but it has its own drawbacks including poor patient compliance and the diagnosis being done in late cases when the lesions looks clinically malignant.

The patients in this series were of the age between 18 and 65 years. Most of the patients were elderly and the maximum number of patients were of age group 42 - 50 years (25\%). Bharti et al[11] states that sex ratio was 7: 1 with male predominance. In our study also males (76.67\%) were affected more than females (23.33\%) and the male: female ratio was 3.2: 1. Probably as tobacco chewing, smoking and alcohol was more common in males. In our study, $71.66 \%$ of the patients presented with oral ulcerations followed by burning sensation in the oral cavity as the second most common symptom seen in about $51.66 \%$ of the patients, difficulty in swallowing in $40 \%$ of the patients, difficulty in mouth opening in $10 \%$, swelling in neck in about $8.33 \%$ and change in voice in $1.66 \%$. Other studies show that ulceration is the most common presentation in malignant lesions. [12]

In our study of 60 cases, non-healing ulcer (premalignant lesions) in $48.33 \%$ of cases followed by clinically malignant lesions was seen in $41.66 \%$ cases, erythroplakia in $5 \%$ of cases, $3.33 \%$ cases of leukoplakia and lichen planus in $1.66 \%$ of cases.[13] Swelling was the most common clinical type in their present study for malignant lesions and white lesions is the most common for premalignant lesions.
Tobacco chewing was the most important risk factor, which was more common among male population (86.67\%) followed by smoking (66.66\%) and alcohol consumption $(60 \%)$ and dual addiction of tobacco chewing and smoking with or without alcohol consumption caused more of incidence of malignant lesions individually.[14] Many studies reported high incidence of tobacco chewing in 58 patients $(58.57 \%)$ in the form of bidi, cigarette or both in their study.

In our study the most common site involved was tongue in approximately $51.67 \%$ cases, buccal mucosa was the second most common site to be involved in $31.67 \%$ cases. Bharti Jha et al similarly found tongue (38\%) as the common site for premalignant lesion followed by floor of mouth (28\%).

The sensitivity, specificity, positive and negative predictive values for malignant lesions were 92.7\%, 80\%, $98 \%$ and $50 \%$. Sensitivity and specificity with regards to premalignant lesions could not be calculated due to very less sample size $(n=5)$.

In the comparison of histology and brush cytology, null hypothesis was considered. Analysis of this showed there is a statistically significant association seen between the findings of brush cytology and biopsy report $(\mathrm{p}<0.05)$, showing that brush cytology findings are associated with biopsy findings.

\section{CONCLUSION}

Oral brush cytology is an important screening tool for early diagnosis of oral cancer and is the key factor for its effective management. The fact that it is painless, easy to perform, has better patient compliance, high specificity in both malignant and premalignant lesions makes it an ideal screening test. The patients with premalignant conditions should be paid special attention for easy diagnosis, because their effective management can stop further malignant transformation and morbidity. All the cases were found to be associated with tobacco chewing, smoking and alcohol. Early diagnosis of precancerous and cancerous lesions with awareness regarding hazards of tobacco is strongly recommended.

\section{REFERENCES}

[1] Mehrotra R, Singh M, Kumar D, et al. Age specific incidence rate and pathological spectrum or oral cancer in Allahabad. Indian J Med Sci 2003;57(9):4004.

[2] Parkin DM, Laara E, Muir CS. Estimates of the worldwide frequency of sixteen major cancers in 1980. Int J Cancer 1988;41(2):184-97.

[3] Scully C, Sudbo J, Speight PM. Progress in determining the malignant potential of oral lesions. J Oral Pathol Med 2003;32(5):251-6.

[4] Gupta PC, Nandakumar A. Oral cancer scene in India. Oral Dis 1999;5(1):1-2.

[5] Scheifele C, Reichart PA. Is there a natural limit of the transformation rate of oral leukoplakia? Oral Oncol 2003;39(5):470-5.

[6] Hayama FH, Motta AC, Silva Ade P, et al. Liquid based preparations versus conventional cytology: specimen adequacy and diagnostic treatment in oral lesions. Med Oral Pathol Oral Cir Bucal 2005;10(2):115-22.

[7] Peters H, Rijsinghani K. The cytologic interpretation of the mouth smear; cell changes in cancer and other diseases. J Indian Med Assoc 1956;27(7):231-6. 
[8] Henry SC, Stahl SS, Lester CR, et al. Exfoliative cytology for detection of early mouth cancer. Oral Surgery, Oral Medicine, Oral Pathology 1960;13(8):994-1009.

[9] Gale N, Pilch BZ, Sidransky D, et al. Tumours of the hypopharynx, larynx and trachea (Epithelial precursor lesions) In: Barnes L, Eveson JW, Reichart P, et al. (eds). World Health Organization Classification of Tumours Pathology \& genetics Head and neck tumours International Agency for Research on Cancer (IARC) Lyon: IARC Press, 2005:140-3.

[10] MacDonald G. Classification and histopathological diagnosis of epithelial dysplasia and minimally invasive cancer. Satellite symposium on epithelial dysplasia and borderline cancer of the head and neck. Controversies and future directions. Joint BSOMP, BSOM, BAHNO Meeting, Oxford, 2003.
[11] Jha BM, Roy A, Jana SH, et al. Scrape cytology-can it replace punch biopsy in diagnosing oral lesions? Int J Med Sci Public Health 2014;3(2):224-8.

[12] Mashberg A, Merletti F, Boffetta P, et al. Appearance, site of occurrence and physical and clinical characteristics of oral carcinoma in Torino, Italy. Cancer 1989;63(12):2522-7.

[13] Rasheed RH. Oral cancer in Iraq. Clincopathological study. M.Sc thesis. College of Dentistry, University of Baghdad, 1989.

[14] Pindborg JJ, Renstrup G, Poulsen HE, et al. Studies in oral leukoplakias. V. Clinical and histological signs of malignancy. Acta Odontol Scand 1963;21:407-14. 